\title{
IS THE HAIRY VAGINULA AN DIAGNOSTIC FEATURE IN THE TAXONOMY OF THE GENUS ORTHOTRICHUM?
}

\author{
VÍTĚZSLAV PLÁŠEK ${ }^{1}$, JAKUB SAWICKI ${ }^{2}$ \\ ${ }^{1}$ Department of Biology and Ecology, \\ University of Ostrava, Chittussiho 10 \\ CZ-710 00, Czech Republic \\ 2 Department of Botany and Nature Protection, \\ University of Warmia and Mazury in Olsztyn \\ Plac Łódzki 1, 10-727 Olsztyn, Poland \\ e-mail: jakub.sawicki@uwm.edu.pl
}

(Received: September 29, 2009. Accepted: January 11, 2010)

\begin{abstract}
The location of stomata and the structural details of exostome teeth and endostome segments are among the most important taxonomic features used for identifying Orthotrichum species. Certain species pairs (e.g. O. stramineum vs. O. pallens; $O$. pumilum vs. $O$. stellatum) are distinguished based on the presence or absence of hair on the vaginula. The authors have shown that this feature is not always appropriate for species identification. Some specimens of $O$. affine, $O$. anomalum or $O$. speciosum were found to have a hairy vaginula, although this feature is not included in their description. The confusion with species determination was resolved in a subsequent DNA analysis of the specimens. The reliability of this character is briefly discussed in the paper.
\end{abstract}

KEY WORDS: Orthotrichum, taxonomy, hairy vaginula, ITS, ISSR, ISJ.

\section{INTRODUCTION}

Most keys for the genus Orthotrichum use the same taxonomic characters which are modified according to the author's concept and species richness in the region. The main characters are the location of stomata, sexuality and the structural details of exostome teeth and endostome segments. One of the crucial character while distinguishing between similar species is presence or absence hairs on the vaginula.

A revision of the genus Orthotrichum was made in the years 1998-2008. About 6500 herbarium specimens originating from the territory of Central Europe were checked (from BRNM, OP, PR, PRC, TC, SOSN, SUM, WRSL, and private collections). During the studies plants with a hairy vaginula were found within species that had been described as having a glabrous vaginula. The presence of a hairy vaginula was recorded in three species of the genus Orthotrichum considered as species with a glabrous vaginula, including one case in $O$. affine, three cases in $O$. anomalum and eight cases in $O$. speciosum. The number of populations with an untypical hairy vaginula may seem negligibly small as compared with the total number of revised specimens, but their presence indicates that this character is not completely stable and shows some variability.
The objective of this study was to determine whether specimens of $O$. speciosum with a hairly vaginula are genetically different from typical plants. O. speciosum was selected since it has a clear taxonomic position, well defined with respect to molecular features (Sawicki et al. 2009a). Moreover, no hybridization processes were observed in $O$. speciosum (Sawicki et al. 2008). In case of $O$. affine and $O$. anomalum, direct comparison of the specimens with glabrous and hairy vaginula is difficult due to several reasons. First, only one specimen of $O$. affine and three $O$. anomalum specimens with hairy vaginula were found, and the second is high intraspecific variation with possibility of cryptic speciation (Sawicki et al. 2009a) and hybridization (Sawicki et al. 2008).

Three categories of molecular markers were used to analyze possible molecular differences between specimens with a hairy vaginula and typical plants. The ITS region had already been used in studies of the genus Orthotrichum (Plášek et al. 2009; Sawicki et al. 2009a, b), was analyzed. ITS sequences in studies of the genus Schistidium (Goryunov et al. 2007) helped to discriminate taxa whose status had been frequently questioned by botanists, which provided another argument for their application in the present study. ISSR (Inter-simple Sequence Repeats) markers are widely used in both taxonomic and population genetics 
studies of bryophytes (Hassel and Gunnarsson 2003; Vanderpoorten et al. 2003; Gunnarsson et al. 2005). These markers proved to be an effective tool in species delimitation, even when ITS sequences fail (Vanderpoorten et al. 2003). Semi-specific ISJ (intron-exon splice junction) markers are based on sequences which are commonly found in plants and which are indispensable for post-transcription DNA processing (Weining and Langridge 1991). These markers had been successfully applied in taxonomic studies of the genera Polygonatum (Szczecińska et al. 2006), Sphagnum (Sawicki and Zieliński 2008), Aneura (Bączkiewicz et al. 2008) and Chamaedaphne (Szczecińska et al. 2009). ISJ markers associate to a sequence on the exon-intron boundary and they are able to amplify functional regions of a genome, that may include genes responsible for appearance of the vaginula.

\section{MATERIALS AND METHODS}

\section{Materials}

Molecular analyses included 16 specimens representing populations of Orthotrichum speciosum mainly from Central Europe. Eight of the analyzed samples had a hairy vaginula. The list of specimens used in a molecular analysis and the details concerning voucher data are given in Appendix 1. To create phylogenetic trees, ITS sequences of additional species from subgenus Gymnoporus from previous studies (Plášek et al. 2009; Sawicki et al. 2009a, b) were used.

\section{Morphological studies}

Due to the fact that the presence of a hairy vaginula was observed repeatedly in some species, selected plants were subjected to a detailed study of their morphological features, with the aim to confirm that they did not belong to a different (unknown) species. The following features were compared: the size, color and sexual condition of plants, the length and shape of the capsule, the length of seta, the size and shape of leaves, the character and location of stomata, the number and surface area of exostome teeth and endostome segments. In addition, the size of the spores was also measured. None of the studied characters showed significant differences.

\section{DNA extraction}

Total genomic DNA was extracted from the herbarium material. Single stems were ground with silica beads in a Mini-BeadBeater-1 tissue disruptor for 50 seconds, and were subsequently processed using the DNeasy ${ }^{\circledR}$ Plant Mini Kit (Qiagen) following the manufacturer's protocol. Extracted DNA samples were stored at $-20^{\circ} \mathrm{C}$.

\section{ITS amplification and sequencing}

The primers proposed by Fiedorow et al. 1998 were used for ITS amplification and sequencing. The ITS region was amplified in a volume of $25 \mu \mathrm{l}$ containing $20 \mathrm{mM}$ $\left(\mathrm{NH}_{4}\right) \mathrm{SO}_{4}, 50 \mathrm{mM}$ Tris- $\mathrm{HCl}\left(\mathrm{pH} 9.0\right.$ at $\left.25^{\circ} \mathrm{C}\right), 1.5 \mathrm{mM}$ $\mathrm{MgCl}_{2}, 1 \mu \mathrm{l}$ BSA, $200 \mu \mathrm{M}$ dATP, dGTP, dCTP, dTTP, 1.0 $\mu \mathrm{M}$ of each primer, one unit of Taq polymerase (Novazym) and $1 \mu \mathrm{l}$ of a DNA solution. The reaction was processed at $94^{\circ} \mathrm{C}$ for $1 \mathrm{~min}$. followed by 30 cycles at $94^{\circ} \mathrm{C}$ for $1 \mathrm{~min}$., $59^{\circ} \mathrm{C}$ for $1 \mathrm{~min}$., and $72^{\circ} \mathrm{C}$ for $1.5 \mathrm{~min}$., with a final extension step of $72^{\circ} \mathrm{C}$ for $5 \mathrm{~min}$. Finally, $5 \mu \mathrm{l}$ of the amplification products was visualized on $1.5 \%$ agarose gel with ethidium bromide staining. Purified PCR products were purified using the ABI BigDye XTerminator Purification Kit (Applied Biosystems) and sequenced in both directions using the ABI BigDye 3.1 Terminator Cycle Kit (Applied Biosystems) and were visualized using an ABI Prism 3130 Automated DNA Sequencer (Applied Biosystems).

TABLE 1. Sequence of 18 primers successfully used in the ISSR and ISJ analysis and number of amplified bands per primer.

\begin{tabular}{|c|c|c|c|}
\hline Primer & Seguence $\left(5^{\prime}-3^{\prime}\right)$ & Number of the amplified bands & Number of polymorphic bands \\
\hline IS810 & $(\mathrm{GA})_{8} \mathrm{~T}$ & 20 & 15 \\
\hline IS819 & $(\mathrm{GT})_{8} \mathrm{~A}$ & 6 & 2 \\
\hline IS822 & $(\mathrm{TC})_{8} \mathrm{~A}$ & 6 & 2 \\
\hline IS825 & $(\mathrm{AT})_{8} \mathrm{G}$ & 11 & 9 \\
\hline IS828 & $(\mathrm{TG})_{8} \mathrm{~A}$ & 8 & 5 \\
\hline IS831 & $(\mathrm{ACC})_{6}$ & 12 & 10 \\
\hline IS834 & $\mathrm{AT}(\mathrm{GAT})_{5} \mathrm{G}$ & 12 & 11 \\
\hline IS840 & ACTTCCCCACAGGTTAACACA & 13 & 11 \\
\hline IS846 & GGGT(GGGGT) ${ }_{2} \mathrm{G}$ & 12 & 7 \\
\hline ISJ 2 & ACTTACCTGAGGCGCCAC & 11 & 7 \\
\hline ISJ 5 & CAGGGTCCCACCTGCA & 13 & 10 \\
\hline ISJ 6 & ACTTACCTGAGCCAGCGA & 14 & 11 \\
\hline ISJ 8 & GACCGCTTGCAGGTAAGT & 12 & 7 \\
\hline ISJ 9 & AGGTGACCGACCTGCA & 8 & 2 \\
\hline ISJ 10 & ACTTACCTGCATCCCCCT & 10 & 4 \\
\hline ISJ 12 & GGACTGGAGCAGGTAAGT & 12 & 5 \\
\hline \multicolumn{2}{|r|}{ Total } & 206 & 135 \\
\hline
\end{tabular}




\section{ISJ markers}

ISJ makers were used as described by Sawicki and Szczecińska (2007). Twelve ISJ primers were initially screened on 5 individuals representing different populations, and eight primers that amplified reproducible products were selected for further study (Table 1). ISJ-PCR reactions were performed in $20 \mu \mathrm{l}$ of a reaction mixture containing $40 \mathrm{ng}$ genomic DNA, $1 \mathrm{\mu M}$ primer, $1.5 \mathrm{mM}$ $\mathrm{MgCl}_{2}, 200 \mu \mathrm{M}$ dNTP (dATP, dGTP, dCTP, dTTP), 1x PCR buffer $\left(20 \mathrm{mM}\left(\mathrm{NH}_{4}\right) \mathrm{SO}_{4}, 50 \mathrm{mM}\right.$ Tris-HCl, pH 9.0 at $\left.25^{\circ} \mathrm{C}\right), 1 \mu \mathrm{BSA}$ and $1 \mathrm{U}$ Genomic RedTaq polymerase (Sigma). ISJ marker reactions were performed under the following thermal conditions: (1) initial denaturation 5 minutes at a temperature of $94^{\circ} \mathrm{C},(2)$ denaturation -1 minute at $94^{\circ} \mathrm{C}$, (3) annealing -1 minute at $52^{\circ} \mathrm{C}$, (4) elongation - 1'30' at $72^{\circ} \mathrm{C}$, final elongation -7 minutes at $72^{\circ} \mathrm{C}$. Stages $2-4$ were repeated 40 times.

\section{ISSR markers}

Twenty-five ISSR primers were initially screened on five individuals representing different populations, and ten primers that amplified reproducible products were selected for further study (Table 1). ISSR-PCR reactions were performed in $20 \mu \mathrm{l}$ of a reaction mixture containing $40 \mathrm{ng}$ genomic DNA, $1.0 \mu \mathrm{M}$ of primer, $1.5 \mathrm{mM} \mathrm{MgCl}_{2}, 200 \mu \mathrm{M}$ each dATP, dGTP, dCTP, dTTP, 1x PCR buffer $(20 \mathrm{mM}$ $\left(\mathrm{NH}_{4}\right) \mathrm{SO}_{4}, 50 \mathrm{mM}$ Tris- $\mathrm{HCl}, \mathrm{pH} 9.0$ at $\left.25^{\circ} \mathrm{C}\right), 1 \mu \mathrm{BSA}$ and $1 \mathrm{U}$ Genomic Red Taq polymerase (Sigma). ISSR marker reactions were performed under the following thermal conditions: (1) initial denaturation -5 minutes at a temperature of $94^{\circ} \mathrm{C},(2)$ denaturation -1 minute at $94^{\circ} \mathrm{C},(3)$ annealing -1 minute at $49^{\circ} \mathrm{C}$, (4) elongation -1 ' $30^{\prime \prime}$ at $72^{\circ} \mathrm{C}$, final elongation -7 minutes at $72^{\circ} \mathrm{C}$. Stages 2-4 were repeated 34 times.

\section{Data analysis}

Amplified bands were scored as present (1) or absent (0) on gels, and PCR reactions were conducted in duplicate to confirm the reproducibility of banding patterns. The statistical analysis was based on 198 loci. All bands that could be reliably read were treated as single dominant loci and scored either present (1) or absent (0) across all genotypes. Genetic diversity (measured as the percentage of polymorphic bands $(\mathrm{P})$, gene diversity $(\mathrm{H})$ and effective number of alleles (A)), genetic identity and number of private alleles were calculated using GenAlEx 6.1 (Peakall and Smouse 2006). Phylogenetic analysis of a binary data was accomplished by using maximum parsimony in PAUP* $4.0 \mathrm{~b} 10$ (Swofford 2003). Multiple most-parsimonious trees were summarized with a strict consensus tree and bootstrapped with 1000 replicates.

Electropherograms were edited and assembled using Sequencher 4.5 (Genecodes Inc.). The assembled sequences were aligned manually with BioEdit 7 (Hall 1999). Phylogenetic analyses of ITS sequences were conducted using Minimum Evolution (ME) analysis (Rzhetsky and Nei 1992) as implemented in MEGA 4 (Tamura et al. 2007). The pairwise distances were estimated with the Kimura 2parameter method (Kimura 1980) and initial trees were generated using the neighbor-joining (NJ) method. The ME tree was searched using the Close Neighbor Interchange (CNI) algorithm (Nei and Kumar 2000) at a search level of 2 , and the maximum number of trees retained at each step was set to 100. Bootstrap analysis (Felsenstein 1985) was carried out with 1000 replicates.

\section{RESULTS}

The three analyzed species $(O$. affine, $O$. speciosum and $O$. anomalum) did not show morphological differences except for presence of hair on the vaginula. The populations of these species that being typically vaginula-naked and presence of hairs in the vaginula could have been simply not noticed by bryologists, due to its rarity or no further importance was given to it. Therefore, the variability of this feature, described recently, could have been often overlooked in the past. These specimens, i.e. Orthotrichum affine, $O$. anomalum and $O$. speciosum, were recorded (see the list in the Appendix) and their vaginulae were photographed (see Fig. 1)

An analysis of 16 accessions of $O$. speciosum, performed using eighteen primers representing two DNA marker categories, enabled 206 bands to be distinguished, of which $65.5 \%$ were polymorphic (Table 2). Eight ISJ primers amplified a total of 94 bands (11.75 bands per primer), while ten ISSR primers revealed 112 bands (11.2 bands per primer). All primers amplified fragments across the 16 samples studied, with the number of amplified fragments ranging from six (ISSR-819 and ISSR-822) to 20 (ISSR-810). The greatest number of bands was identified in the sample from the village of Ruś (144), and the lowest number of bands was amplified in the sample from Wrangler Island (102).

TABLE 2. Number of analyzed specimens $(\mathrm{N})$, percent of polymorphic loci $(\mathrm{P})$, gene diversity $(\mathrm{H})$ and mean effective number of alleles $(\mathrm{A})$ in studied group of $O$. speciosum.

\begin{tabular}{lcccc}
\hline Group & $\mathrm{N}$ & $\mathrm{P}$ & $\mathrm{H}$ & $\mathrm{A}$ \\
\hline Typical & 8 & 0.485 & 0.170 & 1.279 \\
Hairy vaginula & 8 & 0.535 & 0.212 & 1.366 \\
\hline Total & $\mathbf{1 6}$ & $\mathbf{0 . 6 5 5}$ & $\mathbf{0 . 2 1 9}$ & $\mathbf{1 . 3 5 8}$ \\
\hline
\end{tabular}

The molecular diversity of $O$. speciosum specimens, calculated based on ISSR and ISJ bands, was relatively high at $\mathrm{A}=1.358$ and $\mathrm{H}=0.219$. A higher degree of polymorphism was observed in the group of samples with a hairy vaginula, which had $53.5 \%$ polymorphic loci (Table 2). The degree of polymorphism in the group of typical specimens was a little lower $(48.5 \%)$. The effective number of alleles and genetic diversity for samples with and without a hairy vaginula reached $\mathrm{A}=1.366, \mathrm{H}=0.212$ and $\mathrm{A}=1.279$, $\mathrm{H}=0.170$ respectively.

The applied DNA markers did not reveal group-specific bands. Private alleles were observed in the analyzed groups, but they were not found in every sample of the given group. Ten of 16 private alleles were determined in specimens with a hairy vaginula, and six alleles appeared only in the group of typical samples. However, most of private alleles had low frequency, and appeared in one or two samples from each group. Only one private allele in the group of specimens with a hairy vaginula was present in four samples. 

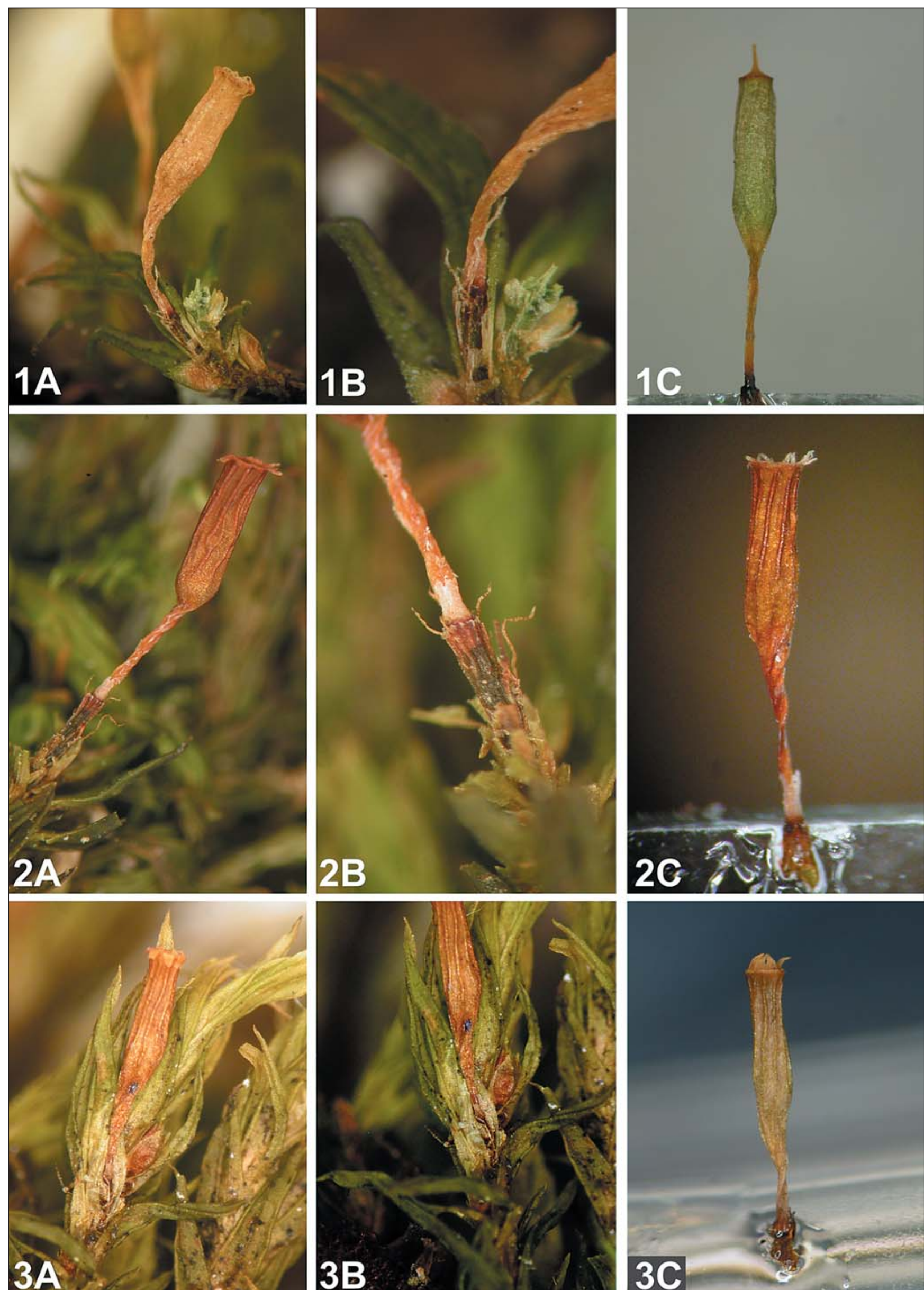

3B

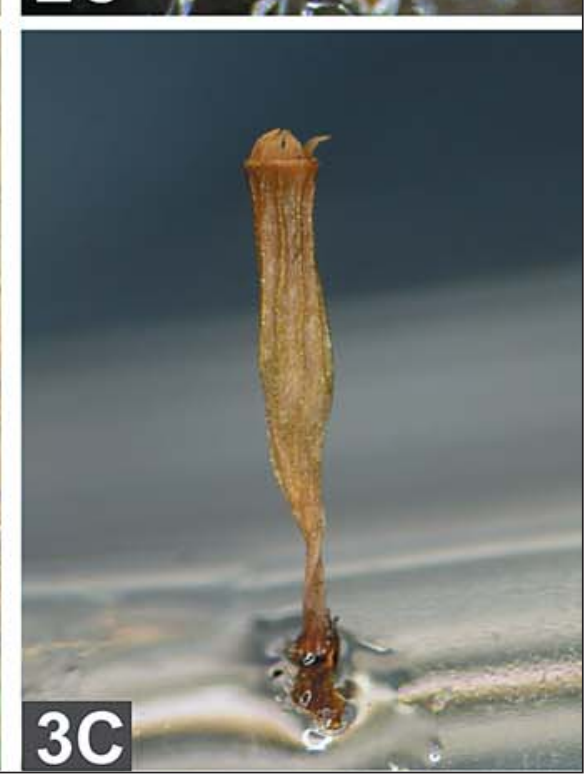

Fig. 1. Photographs comparing the tree species of the genus Orthotrichum with hairy and naked vaginula: A = general view of the plants with hairy vaginula; $\mathrm{B}=$ detailed view on hairs; $\mathrm{C}=$ typical plants with glabrous vaginula. $1=$ O. speciosum $; 2=$ O. anomalum; $3=O$. affine. 


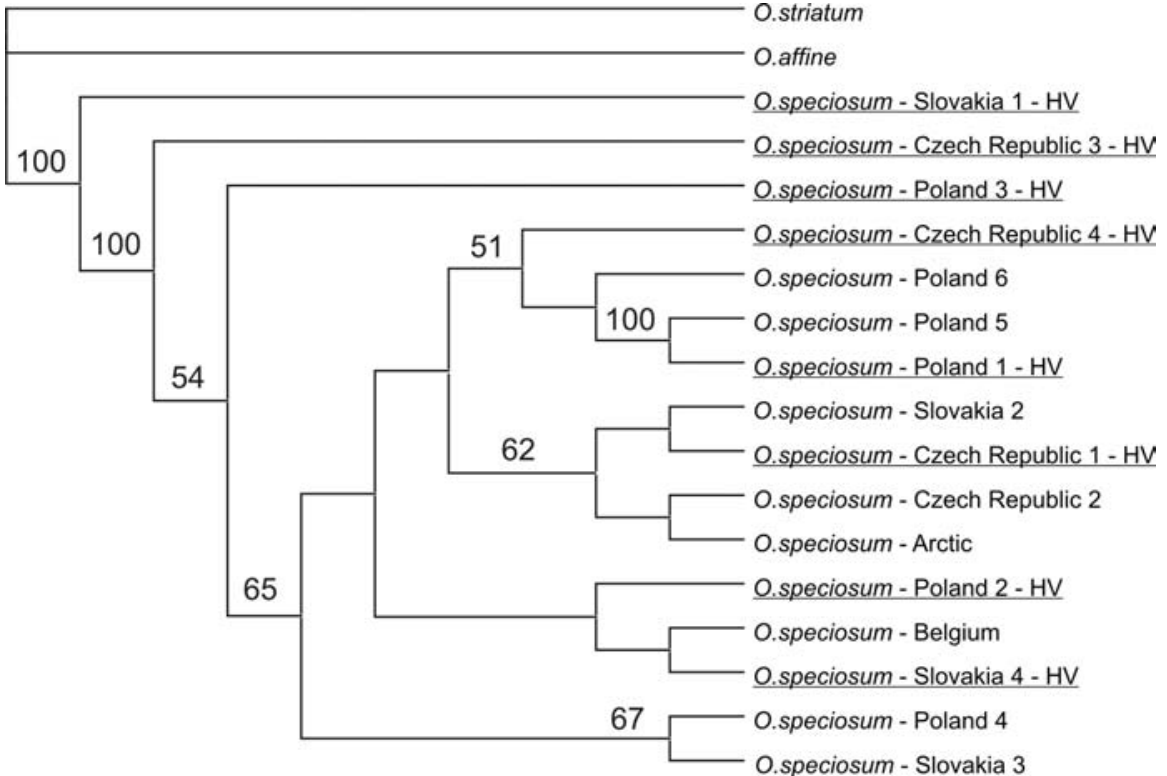

Fig. 2. NJ grouping of analyzed $O$. speciosum specimens based on ISJ and ISSR markers. Boostrap support values are given above branches. Samples of $O$. speciosum with hairy vaginula are underlined.
Genetic differences between the analyzed samples were also validated by the average genetic identity coefficient which reached $\mathrm{I}=0.762$. The lowest degree of genetic identity $(\mathrm{I}=0.566)$ was noted between the sample from Slovakia (1-HV, hairy vaginula) and the sample from Poland (Poland-5, typical vaginula), while the sample from Wrangel Island (Arctic, typical) and Bohemia (Czech Republic-2, typical) populations proved to be most similar ( $\mathrm{I}=0.919)$. The average value of genetic identity within groups with and without a hairy vaginula was 0.735 and 0.805 , respectively. Genetic identity between the above groups reached $\mathrm{I}=0.942$. The noted genetic identity values were consistent with the results of population grouping by the NJ method (Fig. 2). Samples with and without a hairy vaginula did not form separate clades.
An analysis of ITS sequences revealed no differences between the examined groups (Fig. 3). In all analyzed $O$. speciosum specimens the length of the sequences amplified with ITS1 and ITS2 primers was identical, reaching 416 and 452 bp respectively. No intraspecific variation was observed within ITS, either.

\section{DISCUSSION}

The applied molecular markers showed no differences between $O$. speciosum samples with and without a hairy vaginula. In the case of ISSR and ISJ markers, the level of genetic variation was similar to that reported by Snall et al. (2004). These authors analyzed $O$. speciosum populations

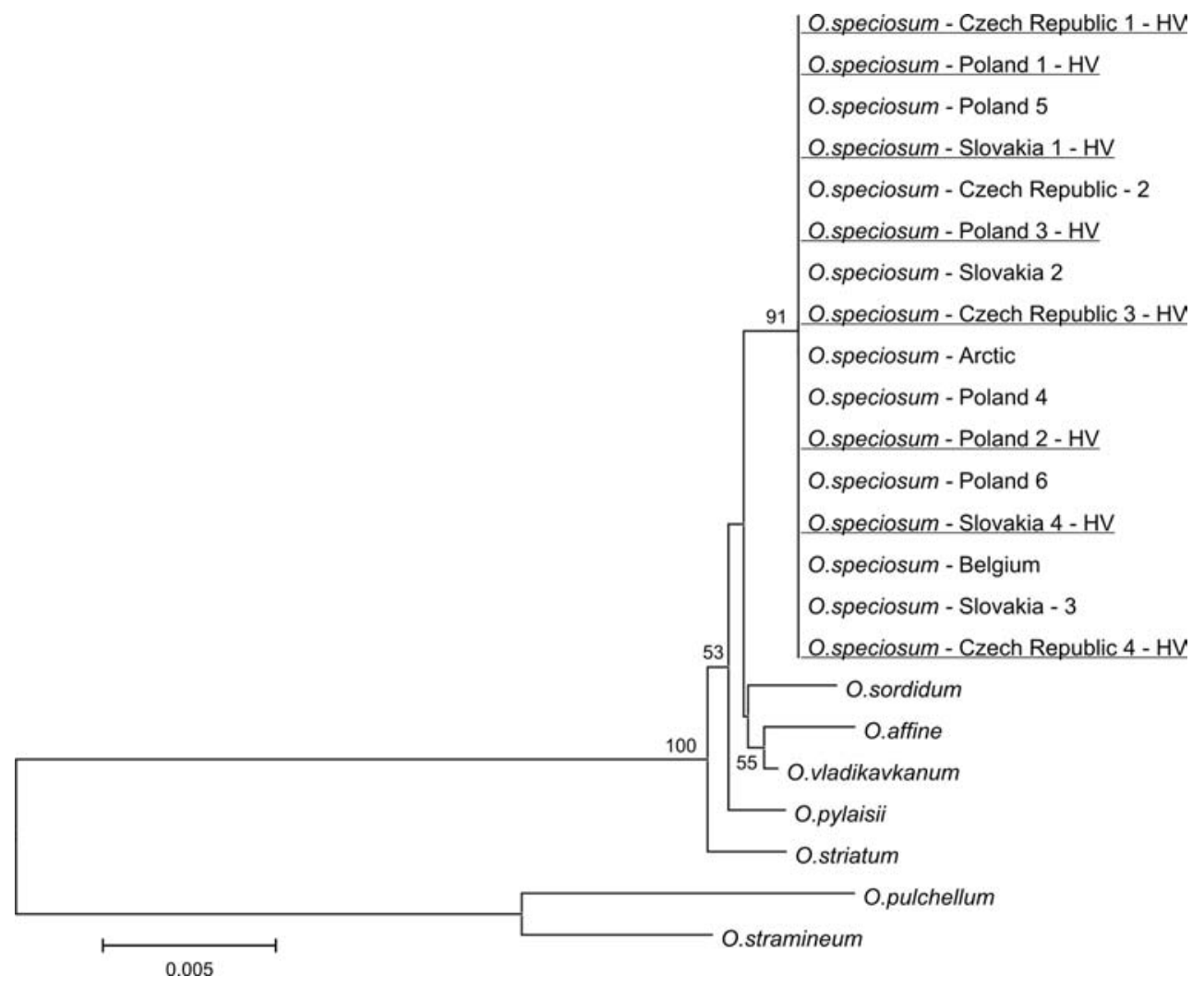

Fig. 3. Minimum Evolution tree based on ITS sequences. Bootstrap values are given above branches. Samples of $O$. speciosum with hairy vaginula are underlined. 
using AFLP markers and determined polymorphism at a level of $65.5 \%$. ISJ and ISSR markers, which proved to be good species-specific markers (Vanderpoorten et al. 2003; Szczecińska et al. 2006; Sawicki and Zieliński 2008; Bączkiewicz et al. 2008), revealed no differences between samples with a hairy vaginula and typical samples. Although the analysis involved a relatively large number of loci, a band correlated with the occurrence of a hairy vaginula was not found. Private alleles were noted in both groups, but they were not characteristic of all samples in a given group. The absence of differences between the investigated forms was also confirmed by a high value of the genetic identity coefficient $(\mathrm{I}=0.942)$, higher than the average values determined within the analyzed groups. The NJ tree based on ISJ and ISSR data suggest that the presence of hairs on vaginula is unlikely to indicate common ancestry.

The ITS region, which usually enables molecular identification of species within the genus Orthotrichum (Plášek et al. 2009; Sawicki et al. 2009a, b), showed no differences between the examined forms of $O$. speciosum. Despite the use of a high number of samples, no intraspecific variation was noted in the ITS region, either. This is consistent with the results of previous studies of the subgenus Gymnoporus (Sawicki et al. 2009a), in which O. speciosum and O. pylaisii were the only species for which no variation was observed in the analyzed sequences.

The presence or absence of a hairy vaginula in O. speciosum individuals seems to be determined by ecological rather than genetic factors, including microclimatic conditions and the effect exerted by phorophytes. The negative impact of human activities on the habitat cannot be excluded, either. Epiphytes are particularly sensitive to the above factors. An analysis of the localities of plants with a hairy vaginula showed that the majority of habitats were situated in close proximity to cities or villages with a potential effect on human activities. It should be also noted that four of eight samples of $O$. speciosum with a hairy vaginula were reported from the bark of Malus domestica, which may indicate the impact of phorophytes on the occurrence of this feature. O. speciosum is very rarely found on this tree species in Central Europe. It grows more often on Acer sp. div., Salix sp. div. or Fagus sylvatica (cf. Schäfer-Verwimp 2001; Wierzcholska and Plášek 2006). In the Czech Republic O. speciosum was found on the bark of Malus in only three percent of cases during the last 20 years (Plášek, unpublished). It is possible that the morphological changes observed in $O$. speciosum could result from growing near the edge of its ecological amplitude.

The wide variability of the investigated feature has been described by other authors: "vaginula naked or sparsely hairy" in Orthotrichum vittii (Lara et al. 1999), "vaginula naked or with short, smooth and brown hair" in O. casasianum (Mazimpaka et al. 1999), "vaginula naked or with sparse, smooth hair" in O. underwoodii (Garilleti et al. 2001). This suggests that this character should be used very carefully and rather as a complementary, not essential, feature. This will allow to avoid confusion with the identification of certain species. Furthermore, it was found that the length of hair on the vaginula is a highly variable character. For example, both plants with long hair reaching the base of the capsule and individuals with very short, sparse hair (similar as e.g. in O. stellatum) were found within O. stramineum. The number of populations with an untypical hai- ry vaginula may seem negligibly small as compared with the total number of revised specimens, but their presence indicates that this character is not completely stable.

\section{ACKNOWLEDGEMENTS}

This study was made possible through financial support from the Ministry of Science and Higher Education (grant N303 416237). The field survey was supported from coffers of Czech Science Foundation (GA CR) No. 206/07/0811. We also thank the anonymous reviewer for helpful commentary on the manuscript.

\section{LITERATURE CITED}

BĄCZKIEWICZ A., SAWICKI J., BUCZKOWSKA K., POLOK K., ZIELIŃSKI R. 2008. Application of different DNA markers in studies on cryptic species of Aneura pinguis (Jungermanniopsida, Metzgeriales). Cryptogamie Bryologie 29(1): 3-21.

FELSENSTEIN J. 1985. Confidence limits on phylogenies: An approach using the bootstrap. Evolution 39: 783-791.

FIEDOROW P., ODRZYKOSKI I., SZWEYKOWSKA-KULIŃSKA Z. 1998. Phylogenetic studies of liverworts using molecular biology techniques. In: Plant Cytogenetics. Małuszyńska J. (ed.). Katowice pp. 244-249.

GARILLETI R., LARA F., MAZIMPAKA V. 2001. Orthotrichum underwoodii, sp. nov. (Orthotrichaceae, Bryosida) from California. Bryologist 104(2): 268-273.

GORYUNOV D.V., IGNATOVA E.A., IGNATOV M.S., MILYUTINA I.A., TROITSKY A.V. 2007. Support from DNA data for narrow species concept in Schistidium (Grimmiaceae, Musci). J. Bryol. 29: 98-103.

GUNNARSSON U., HASSEL K., SODERSTROM L. 2005. Genetic structure of the endangered peat moss Sphagnum angermanicum in Sweden: a result of historic or contemporary processes? Bryologist 108: 194-203.

HALL T.A. 1999. BioEdit: a user-friendly biological sequence alignment editor and analysis program for Windows 95/98/NT. Nucleic Acids Symposium Series 41: 95-98.

HASSEL K., GUNNARSSON U. 2003. The use of inter simple sequence repeats (ISSR) in bryophyte population studies. Lindbergia 28: 152-157.

KIMURA M. 1980. A simple method for estimating evolutionary rate of base substitutions through comparative studies of nucleotide sequences. J. Mol. Evol. 16: 111-120.

LARA F., MAZIMPAKA V., GARILLETI R., GARCÍA-ZAMORA P. 1999. Orthotrichum vittii, a new epiphytic moss from Spain. Bryologist 102(1): 53-60.

MAZIMPAKA V., LARA F., GARILLETI R., INFANTE M., HERAS P. (1999). Orthotrichum casasianum, a new epiphytic moss from humid forests of Northern Spain. J. Bryol. 21: 47$-53$.

NEI M., KUMAR S. 2000. Molecular Evolution and Phylogenetics. Oxford University Press, New York.

PEAKALL R., SMOUSE P. 2006. GENALEX 6: genetic analysis in Excel. Population genetic software for teaching and research. Mol. Ecol. Not. 6: 288-295.

PLÁŠEK V., SAWICKI J., TRÁVNÍČKOVÁ V., PASEČNÁ M. 2009. Orthotrichum moravicum (Orthotrichaceae), a new moss species from the Czech Republic. Bryologist 112(2): 329-336.

RZHETSKY A., NEI M. 1992. A simple method for estimating and testing minimum evolution trees. Mol. Biol. Evol. 9: 945$-967$.

SAWICKI J., PLÁŠEK V., SZCZECIŃSKA M. 2008. Testing candidate $t r n \mathrm{H}-p s b \mathrm{~A}$ noncoding plant barcode region in the Orthotrichum genus. Scripta Facultatis Rerum Naturalium Universitatis Ostraviensis 186: 170-177. 
SAWICKI J., PLÁŠEK V., SZCZECIŃSKA M. 2009a. Molecular evidence do not support the current division of Orthotrichum subgenus Gymnoporus. Pl. Syst. Evol. 279: 125-137.

SAWICKI J., PLÁŠEK V., SZCZECIŃSKA M. 2009b. Preliminary Studies on the Phylogeny of the Genus Orthotrichum Inferred from Nuclear ITS Sequences. Ann. Bot. Fenn. 46(6): 507-515.

SAWICKI J., ZIELIŃSKI R. 2008. Phylogenetic relationships between five Sphagnum species of the section Acutifolia Based on DNA markers. Časopis Slezského Zemského Muzea (Sci. Natur.) 57: 63-80.

SAWICKI J., SZCZECIŃSKA M. 2007. Semi-specific intronexon splice junction markers in bryophyte studies. Biodiversity Research and Conservation 5-8: 25-30.

SCHÄFER-VERWIMP A. 2001. Orthotrichum Hedw. In: Die Moose Baden-Württembergs. Nebel M., Philippi G. (eds). Stuttgart, pp. 170-197.

SNALL T., FOGELQVIST J., RIBEIRO P.J.J., LASCOUX M. 2004. Spatial genetic structure in two congeneric epiphytes with different dispersal strategies analysed by three different methods. Mol. Ecol. 13: 2109-2119.

SWOFFORD D.L. 2003. PAUP: Phylogenetic Analysis Using Parsimony (and Other Methods) (Sinauer, Sunderland, MA), 4.0 Beta.
SZCZECIŃSKA M., SAWICKI J., POLOK K., HOŁDYŃSKI C., ZIELIŃSKI R. 2006. Comparison of the Polygonatum species from Poland on the basis of different DNA markers. Ann. Bot. Fenn. 43(5): 379-388.

SZCZECIŃSKA M., SAWICKI J., WĄSOWICZ K., HOŁDYŃSKI C. 2009. Genetic variation of the relict and endangered populations of Chamaedaphne calyculata (Ericaceae) in Poland. Dendrobiology 62: 23-33.

TAMURA K., DUDLEY J., NEI M., KUMAR S. 2007. MEGA4: Molecular Evolutionary Genetics Analysis (MEGA) software version 4.0. Molecular Biology and Evolution /10.1093/molbev/msm092.

VANDERPOORTEN A., HEDENÄS L., JACQUEMART A.L. 2003. Differentiation in DNA fingerprinting and morphology among species of the pleurocarpous moss genus, Rhytidiadelphus (Hylocomiaceae). Taxon 52: 229-236.

WEINING S., LANGRIDGE P. 1991. Identification and mapping of polymorphisms in cereals based on polymerase chain reaction. Theoretical and Applied Genetics 82: 209-216.

WIERZCHOLSKA S., PLÁŠEK V. 2006. Phorophyte preferences of epiphytic mosses within the Orthotrichaceae family in the Góry Bialskie Mts. (SW Poland). Scripta Facultatis Rerum Naturalium Universitatis Ostraviensis 163: 146-154.

\section{APPENDIX}

$\underline{\text { A }} \underline{\text { list }}$ of herbarium specimens:

\section{Orthotrichum affine Brid.}

Specimen with hairy vaginula:

Czech Republic, part. Bohemia, Český les Mts., 1.7 km NNW of Železná village, near Farský potok stream, 495 m a.s.1., 17.8.1999 leg. Mudra, herb. TC

\section{Orthotrichum anomalum Hedw.}

Specimens with hairy vaginula:

Czech Republic, part. Bohemia, Český les Mts., Konice village, Netřeb reserve, $600 \mathrm{~m}$ a.s.1., 30.4.2005 leg. Mudrová, herb. TC

Czech Republic, part. Moravia, 460 m N of Pulčín village, along a tourist path towards Pulčínské skály rocks, 550 m a.s.1., 26.7.2005 leg. Plášek, herb OP

Slovakia, Tematínské vrchy hills, $1.5 \mathrm{~km} \mathrm{~N}$ of Lúka village, $405 \mathrm{~m}$ a.s.1., 22.4.2006 leg. Plášek, herb. OP

\section{Orthotrichum speciosum Nees}

Specimens with hairy vaginula:

Czech Republic (Czech Republic 1-HV), part. Bohemia, Český les Mts., $300 \mathrm{~m} \mathrm{~N}$ of Broumov town, 12.6.1992 leg. Mudra, herb. TC; GU338785 / GU338772

Czech Republic (Czech Republic 3-HV), part. Silesia, Nízký Jeseník foothill, $8.5 \mathrm{~km}$ NW of Ostrava-Poruba town, center of Zátiší village, $325 \mathrm{~m}$ a.s.1., 8.2.2004 leg. Plášek, herb. OP; GU338786 / GU338773

Czech Republic (Czech Republic 4-HV), part. Silesia, Moravskoslezské Beskydy Mts., loc. Bílý Kř́̌ž, ca. 740 $\mathrm{m} \mathrm{NW}$ of the Czech-Slovak border \& $400 \mathrm{~m} \mathrm{NW}$ of Sulov hill, 849 m a.s.l., 12.9.2006 leg. Plášek, herb. OP; GU338787 / GU338774

Poland (Poland 1-HV), Warmia, Ruś village near Olsztyn, $109 \mathrm{~m}$ a.s.1., 14.08.2007 leg. Sawicki, herb. OLS-M; GU338788 / GU338775
Poland (Poland 2-HV), Mazury, Gałwuny village near Kętrzyn, $73 \mathrm{~m}$ a.s.1., 07.08.2007 leg. Sawicki, herb. OLSM; GU338789 / GU338776

Poland (Poland 3-HV), Mazowsze, Luberadz village near Ciechanów, $95 \mathrm{~m}$ a.s.1., 23.06.2008 leg. Sawicki, herb. OLS-M; GU338790 / GU338777

Slovakia (Slovakia 1-HV), Jablunkovské medzihorie highlands, $5 \mathrm{~km}$ E of Svrčinovec village, Čadečka settlement, 581 m a.s.l., 28.8.2004 leg. Plášek, herb. OP; GU338791 / GU338778

Slovakia (Slovakia 4-HV), Poloniny Mts., NE edge of Runina village, $551 \mathrm{~m}$ a.s.1., 20.6.2006 leg. Plášek, herb. OP; GU338792 / GU338779

Specimens with glabrous vaginula:

Russia (Arctic), Chukotka, Wrangel Island Sominietlaya Bay, $136 \mathrm{~m}$ a.s.1.,15.08.1985 Afonina, herb. NYBG; GU338793 / GU338780

Belgium, Viervers-Sur-Viroin, $150 \mathrm{~m}$ a.s.1. 10.06.2009 Sawicki, herb. OLS-M; GU338794 / GU338781

Czech Republic (Czech Republic-2), Bohemia, Český les Mts, Ostrůvek village, loc. Randezvous, $735 \mathrm{~m}$, 12.4.2000 leg. Mudrová, herb. OP; EU863213 / EU072695

Poland (Poland-4), Bialskie Mts, Stary Gielatów village, 560 m a.s.1., 21.08.2004 leg. Plášek, herb. OP; FJ159258 / FJ168663

Poland (Poland-5), Ruś village near Olsztyn, 107 m a.s.1., 10.07.2006 leg. Sawicki, herb. OLS-M; GU338795 / GU338782

Poland (Poland-6), Krosno village near Orneta town, 64 m a.s.1. 2.11.2007 leg. Sawicki, herb. OLS; GU338796 / GU338783

Slovakia (Slovakia-2), Nízké Tatry Mts, Liptovský Mikuláš distr., ca. $3 \mathrm{~km} \mathrm{~S}$ of Liptovský Ján village, Lipto- 
vský dvôr settlement, 4.2.2007 leg. Plášek, herb. OP; FJ159257 / FJ168664

Slovakia (Slovakia-3), Liptovské Vrchy Mts, $10 \mathrm{~km}$ NE of Liptovský Mikuláš town, N of Prosiek village, loc. Prosiecká dolina valley, 27.5.2003 leg. Plášek, herb. OP; GU338797 / GU338784

Specimens used as outgroups in phylogenetic analyses:

Orthotrichum affine Schrad. ex Brid., Czech Republic, Prov. Bohemia, Pivoň village, herb. OP; EU860400 / EU072690

Orthotrichum pulchellum Brunt., USA, Clallam Country, herb. NYBG; EU443996 / EU484065
Orthotrichum pylaisii Brid., Grenlandia, Godthab distr. Kilearsarfik, Ameragdla, herb. NYBG; EU863210 / EU871637

Orthotrichum sordidum Sull. et Lesq., USA, Connecticut, herb. NYBG; FJ159261 / FJ168666

Orthotrichum stramineum Hornsch. ex Brid., Czech Republic, Prov. Bohemia, Rybník village, herb. OP; EU443999 / EU072696

Orthotrichum striatum Hedw., Poland, Bialskie Mts, Gieraltów village, herb. OP; FJ159256, FJ168676

Orthotrichum vladikavkanum Tadzhikistan, Dushanbe, in Valle Ramit, herb. NYBG; EU863214 / EU871640 